\title{
Praktik Pendidikan Konseling di Pesantren Alhamdaniyah dalam Membina Moralitas Keagamaan Siswa
}

\author{
Su'eb \\ IAI al Khoziny, Sidoarjo, Indonesia \\ mohsyuaib99@gmail.com
}

\begin{abstract}
Abstrak
Tulisan ini mencoba menawarkan gagasan pendidikan konseling di pesantren sebagai suatu model layanan konseling dalam membina moralitas keagamaan. Penelitian ini mengunakan metode riset lapangan dengan teknik analisis deskriptif kualitatif. Data penelitian yang terkumpul kemudian dianalisis dengan menggunakan pendekatan deduktif dan pendekatan induktif yang berkenaan dengan Praktik Pendidikan Konseling di Pesantren dalam Membina Moralitas Keagamaan Siswa. Hasil penelitian menunjukkan bahwa pendidikan konseling pondok pesantren Alhamdaniyah memiliki Kontribusi dalam membinan keagamaan yang tergambar pada layanan kegiatan antara lain melaksanakan Istighosah dan Tahlilan dan pelajaran ta'limul muta'alim. Sehingga berkontribusi dalam membina moralitas keagamaan siswa yang meliputi; siswa memiliki jiwa agamis, siswa tidak melupakan nilai-nilai keagamaan, memiliki ikatan yang erat dengan kyai serta antar pesantren dan sekolah.
\end{abstract}

Kata Kunci: Pendidikan Konseling, Pesantren, Moralitas Keagamaan

\begin{abstract}
COUNSELING EDUCATION PRACTICES AT ALHAMDANIYAH ISLAMIC BOARDING SCHOOL IN FOSTERING STUDENTS' RELIGIOUS MORALITY. This paper attempts to offer the idea of counseling education in Islamic boarding schools as a model of counseling services in fostering religious morality. This study uses field research methods with qualitative descriptive analysis techniques. The research data were analyzed using a deductive approach and an inductive approach with regard to the Counseling Education Practices at Islamic Boarding Schools in Fostering Students' Religious Morality.
\end{abstract}


The results showed that the counseling education of Alhamdaniyah Islamic boarding school had a contribution in establishing religious services illustrated in the activities including implementing Istighosah and Tahlilan and ta'limul muta'alim lessons. This will contribute in fostering the students' religious morality which includes; students have a religious spirit, students do not forget religious values, have a close tie with Kyai as well as among pesantren and schools.

Keywords: Counseling Education, Islamic Boarding School, Religious Morality

\section{A. Pendahuluan}

Kehidupan manusia pada masa kini di warnai dengan kemajuan dalam berbagai macam bidang. Perkembangan ilmu pengetahuan dan teknologi telah membawa manusia kepada taraf kehidupan yang relative lebih maju. Hal ini merupakan keberhasilan manusia dalam rangka pengembangan dirinya. Sebagai sebuah agama, Islam berkembang melalui dua macam struktur, yaitu: struktur keyakinan dan struktur peribadatan (Subandi 2009).

Pendidikan dewasa ini mengemban tugas yang lebih berat, dimana semakin majunya teknologi informatika mengakibatkan degradasi moral semakin kentara saja. Kita tidak bisa disatu sisi menyalahkan arus globalisasi informatika, karena disadari seiring berkembangnya zaman, perkembangan akan teknologi tak bisa terhindarkan, mengingat manusia semakin hari semakin berpikir untuk memudahkan semua proses hidupnya di dunia ini. Namun, seperti hal yang tersebut diatas, hal ini menyebabkan degradasi moral yang tak terhindarkan pula, yang menjadikan manusia melek teknologi, namun kosong moral nya.

Menurut Din Syamsudin ketika menjabat sebagai Wakil Ketua MUI Pusat (Majelis Ulama' Indonesia) menegaskan bahwa masalah yang dihadapi bangsa Indonesia ini berpangkal pada krisis moral. Hal tersebut terjadi karena bangsa Indonesia terjebak dalam permisivisme budaya dengan membiarkan dan mengabaikan proses dekadensi moral yang terjadi secara sistematis tanpa penggerak untuk mengatasi dan menghalanginya (Nugroho 2017:357).

Pendidikan ada dua macam, yakni pendidikan formal dan pendidikan non formal. Pondok pesantren temasuk pada pendidikan non formal, karena saat ini banyak hal yang tengah dialami oleh bangsa ini, salah satunya adalah fenomena merosotnya nilai-nilai moral remaja kita. Merosotnya nilai-nilai moral dalam kehidupan remaja saat ini merupakan keprihatinan kita bersama. Tawuran antar pelajar, maraknya peredaran narkoba dikalangan siswa, adanya siswa yang 
terlibat dalam tindakan kriminal adalah secuil contoh perilaku menyimpang remaja kita. Tidak hanya di kalangan remaja saja, secara umum bangsa Indonesia dihadapkan berbagai problem dan krisis bangsa yang serius. Berbagai permasalahan silih berganti menyita perhatian anak bangsa. Jika tidak segera ditangani dan diatasi, maka problem dan krisis itu bisa mengarah pada bergesernya moral/ karakter remaja Indonesia, dari moral positif ke negatif. Yang diterangkan dalam Al-Qur'an surah An Nur ayat 55.

Artinya: "Dan Allah telah berjanji kepada orang-orang yang beriman di anara kamu dan mengerjakan amal-amal yang saleh bahwa Dia sungguh-sungguh akan menjadikan mereka berkuasa di bumi, sebagaimana Dia telah menjadikan orang-orang yang sebelum mereka berkuasa, dan sungguh Dia akan mengeukuhkan bagi mereka agama yang telah diridhai-Nya untuk mereka, dan Dia benar-benar akan mengukur (keadaan) mereka, sesudah mereka mereka berada dalam ketakutan menjadi aman sentausa." (QS. Al-Nur; 25: 55) (Kemenag RI 2009).

Hal tersebut telah menumbuhkan kesadaran bagi kita betapa pentingnya untuk segera melakukan terobosan guna membentuk dan membina karakter/ moral para remaja sebagai generasi penerus bangsa. Ini perlu dilakukan agar remaja Indonesia tidak terjerumus ke dunia kriminalitas lebih dalam lagi serta diharapkan agar remaja kita saat ini kelak bisa menjadi kader-kader pemimpin umat yang mampu membawa bangsa ini lebih maju lagi dan mampu bersaing di kancah internasional.

Untuk mengatasi masalah-masalah tersebut diatas tidaklah mungkin hanya dapat ditangani oleh para orang tua mereka saja, tetapi antara orang tua, masyarakat dan lembaga pendidikan baik formal maupun non formal harus saling melengkapi dan bertanggung jawab atas usaha pembinaan remaja. Karena lembaga pendidikan merupakan salah satu wadah dalam masyarakat yang bisa dipakai sebagai pintu gerbang dalam menghadapi tuntutan masyarakat, ilmu pengetahuan dan teknologi yang terus mengalami perubahan.

Salah satu lembaga pendidikan yang dianggap mampu mengantisipasi agar remaja kita tidak larut dalam kebejatan akhlak dan mengarahkan mereka agar segala tingkah laku dan tindak tanduknya sesuai dengan ajaran-ajaran agama Islam adalah lembaga pendidikan yang berupa pondok pesantren. Mengapa pesantren? Bagaimana bentuk praktik konseling di pesantren? Pertanyaan tersebut akan dijawab dalam konteks pendidikan konseling di era modern, namun alasan sederhananya ialah bahwa pesantren merupakan lembaga pendidikan Islam yang tidak hanya mengajarkan tentang ilmu-ilmu keagamaan saja, akan tetapi di 
pesantren juga diajarkan tentang pendidikan moral dan akhlak/ tingkah laku yang tidak terdapat di sekolah-sekolah biasa. Oleh karena itu, yang menjadi problem adalah bagaimana pelaksanaan pendidikan konseling di pesantren Alhamdaniyah dalam Membina Moralitas Keagamaan Siswa. Penelitian ini mengunakan metode riset lapangan dengan teknik analisis deskriptif kualitatif. Data penelitian yang terkumpul kemudian dianalisis dengan menggunakan pendekatan deduktif dan pendekatan induktif yang berkenaan dengan Praktik Pendidikan Konseling di Pesantren dalam Membina Moralitas Keagamaan Siswa.

\section{B. Pembahasan}

\section{Hakikat Moralitas Keagamaan}

Moral adalah Nilai-nilai dan norma-norma yang menjadi pegangan bagi seorang atau suatu kelompok dalam mengatur tingkah lakunya (Bertens 2013). Moralitas dari kata sifat latin moralis mempunyai arti yang pada dasarnya sama dengan moral hanya ada nada lebih abstrak. Kita berbicara tentang moralitas suatu perbuatan, artinya segi moral suatu perbuatan atau baik buruknya. Moralitas adalah sifat moral atau keseluruhan asas dan nilai yang berkenaan dengan baik dan buruk (Bertens 2013).

Menurut Zainuddin Saifullah nainggolan, Moral adalah tradisi spiritul untuk melakukan serangkaian standar yang mengatur perilaku orang dan masyarakat. Sedangkan menurut Imam Sukardi, Moral adalah kebaikan bahwa seorang pria dengan langkah-langkah yang diadopsi oleh aksi bersama. Dari kedua pendapat diatas memiliki pengertian yang berbeda-beda. Yang pertama adalah pendapat Zainuddin Saifullah Nainggolan yang menurutnya moral adalah sebuah tradisi yang mengatur perilaku manusia. Sedangkan pendapat yang kedua adalah pendapat milik Imam Sukardi yang menurutnya moral adalah perilaku manusia yang didapat dari kebiasaan bersama.

Moral dibagi menjadi dua: moral keagamaan dan moral sekuler, Moral keagamaan adalah moral yang selalu bergantung pada hal keagamaan. Moral sekuler memiliki pengertian yang berbalik dengan pengertian moral keagamaan. Moral merupakan pengetahuan atau wawasan yang menyangkut budi pekerti manusia yang beradab. Moral juga berarti ajaran tentang baik atau buruknya perbuatan dan kelakuan manusia. Dalam kehidupan manusia, moral menjadi sesuatu yang sangat penting dan harus dimiliki oleh setiap individu. Manusia yang 
mempunyai moral akan senantiasa meakukan hal-hal yang bermoral dan perbuatannya selalu sesuai dengan norma yang berlaku.

Dalam perkembangan selanjutnya, istilah moral sering pula didahului oleh kata kesadaran, sehingga menjadi istilah kesadaran moral. Orang yang memiliki kesadaran moral akan senantiasa jujur, sekalipun tidak ada orang lain yang melihatnya. Tindakan orang yang bermoral tidak akan menyimpang, dan selalu berpegang teguh pada nilai-nilai tersebut. Hal ini terjadi karena tindakan orang yang bermoral itu berdasarkan atas kesadaran, bukan berdasar pada sesuatu kekuatan apapun dan juga bukan karena paksaan, tetapi berdasarkan pada kesadaran moral yang timbul dari dalam diri yang bersangkutan (Nata 2013).

Orang yang kesadaran moralnya telah mendarah daging dalam dirinya, ia akan dengan mudah dapat melakukan suatu pebuatan tanpa harus ada dorongan atau paksaan dari luar. Orang yang demikian adalah orang yang memiliki kesadaran moral, atau orang yang telah bermoral. kamus ilmiah popular memiliki arti kesusilaan, atau kedisiplinan batin. Dalam hal itu bias diambil pengertian bahwasannya moralitas itu sama halnya dengan kedisiplinan perilaku dan bisa disebut sebagai akhlak.

\section{a. Pendidikan dan Budaya Sekolah Dalam Membentuk Moralitas Keagamaan Siswa}

Di Amerika serikat sekolah menjadi semakin penting melalui cara-cara yang tidak bisa diketahui sebelumnya. Walaupun kedengarannya kesal melihat kenyataan yang ada orang mungkin berpendapat bahwa sekolah digunakan sebagai tong sampah institusional, yang menampung segala kegiatan (Dhurkheim 2013).

Menurut Durkhaiem sekolah mempunyai fungsi yang sangat penting dan sangat khusus untuk menciptakan makhluk baru, yang dibentuk sesuai kebutuhan masyarakat. Hanya dengan mengadakan pembatasan maka anak dapat dibebaskan dari frustasi-frustasi yang pasti timbul dalam perjuanagan yang tiada hentihentinya. Hanya kalau anak didik secara sistematis tentang warisan kebudayaan negerinya, maka ia dapat memiliki rasa identitas dan kepuasan pribadinya. Hanya bila ia sadar akan keterlibatannya dalam suatu masyarakat terhadap mana ia diikat oleh kewajiban dan keinginan, maka ia dapat menjadi seorang makhluk yang bermoral (Dhurkheim 2013).

Pendidikan juga memiliki fungsi yang luas, dalam pendidikan terdapat kebudayaan dan pendidikan memiliki peran sebagai fungsi sosial yaitu pendidikan 
merupakan suatu cara yang dilakukan masyarakat dalam membimbing anak yang belum matang sesuai dengan bentuk serta susunan maysrakat itu sendiri. Jadi pendidikan itu mempunyai atau memiliki fungsi untuk meneruskan, menyelamatkan, sumber dan cita-cita masyarakat (Nugroho 2018).

Untuk mengetahui secara jelas peranan penting yang dapat dan harus di mainkan lingkungan sekolah dalam pendidikan moral, pertama-tama kita harus menyadari apa yang di hadapi si anak ketika dia datang ke sekolah. Hingga saat itu ia baru berkenalan dengan dua macam kelompok. Dalam kelompok keluarga, sentimen solidaritas berasal dari hubungan darah dan ikatan moral yang di akibatkan hubungan tersebut selanjutnya di perkuat oleh kontak yang akrab dan konstan antara semua pikiran yang bergaul itu dan oleh kehidupan mereka yang saling mengisi. Kemudian terdapat kelompok-kelompok kecil yang terdiri dari teman dan sahabat, kelompok-kelompok yang telah mengambil bentuk di luar lingkungan keluarga melalui pilihan bebas. Lingkungan sekolah merupakan asosiasi lebih luas dari pada lingkungan keluarga atau teman-teman lingkungan sekolah tidak berasal dari hubungan darah, bukan juga dari pilihan bebas, tetapi dari pertemuan secara kebetulan dan tak dapat di elakkan di antara para murid yang di kumpulkan berdasarkan umur dan berbagai kondisi sosial yang hampir sama, dalam hal ini sekolah menyerupai masyarakat politik, dari situlah kita punya instrumin yang berharga yang belum begitu di manfaatkan dan yang dapat memberikan hasil yang sangat besar (Dhurkheim 2013).

\section{b. Proses Konseling dalam Membentuk Moralitis Keagamaan Siswa}

Pondok pesantren adalah merupakan dua istilah yang mengandung satu arti. Orang Jawa menyebutnya "pondok" atau "pesantren". Sering pula menyebut sebagai pondok pesantren. Istilah pondok barangkali berasal dari pengertian asrama-asrama para santri yang disebut pondok atau tempat tinggal yang terbuat dari bambu atau barangkali berasal dari bahasa Arab "funduq" artinya asrama besar yang disediakan untuk persinggahan.

Dalam menjalankan fungsi dan peranannya yang luas baik itu dalam masyarakat kegiatan pondok pesantren tercakup dalam Tri Darma pondok pesantren yaitu: pertama, mengajarkan keilmuan dan ketaqwaan pada Allah SWT. Kedua, mengajarkan Pengembangan keilmuan yang bermanfaat. Ketiga, mengajarkan pengabdian terhadap agama, masyarakat dan Negara (Kafrawi 1978). 
Keimanan dan ketaqwaan terhadap Allah SWT sudah sejak awal menjadi ciri pokok dari pendidikan pondok pesantren, pengembangan keilmuan yang bermanfaat juga telah menjadi salah satu cirri dari pendidikan pondok pesantren. Hanya pengertian ilmu yang bermanfaat itu perlu diperluas hingga bukan hanya terbatas pada pengetahuan agama dan ilmu-ilmu alatnya seperti bahasa (Nahwu, Shorrof) tetapi juga harus termasuk ilmu pengetahuan umum lainnya. Pengabdian terhadap agama, masyarakat adalah mutlak bagi para santri dan dunia pondok pesantren. Pengabdian terhadap agama, bangsa, dan Negara harus secara serempak dan tidak secara parsil.

\section{c. Potensi Dini Siswa dan Moralitas Keagamaan}

"Tidak ada peserta didik yang tidak memiliki potensi" Ungkapan ini tidaklah berlebihan. Sebab pada hakekatnya setiap peserta didik memiliki potensi. Karena peserta didik itu berbeda-beda, maka potensi yang mereka miliki pun berbeda-beda. Tak terkecuali peserta didik yang memiliki saudara kembar. Banyak pendidik yang menyadari kenyataan ini, tetapi mungkin ada juga oknum pendidik yang tidak menyadarinya sehingga mengeneralisasi anak didiknya dengan potensi yang sama. Jelas, sikap tersebut hanya akan menutup atau bahkan mematikan potensi anak didik. Kalau hal itu benar-benar terjadi, maka tujuan pendidikan yakni memberdayakan setiap anak didik menurut potensi mereka tak kan tercapai (Missa 2014).

Kita tahu, potensi merupakan bagian tak terpisahkan dari kemampuan besar manusia. Sejatinya, kemampuan besar manusia terdiri dari kemampuan aktual, yaitu kemampuan yang ada saat ini, kemampuan yang sudah teraktualisasikan. Contohnya skor IQ, dan skor TOEFL. Kemampuan besar manusia yang lain adalah kemampuan potensial. Disebut potensial karena merupakan kemampuan yang belum tergali, belum teraktualisasikan, kemampuan yang berwujud kemungkinan-kemungkinan. Contohnya adalah bakat.

Potensi adalah kesanggupan, daya, kemampuan untuk lebih berkembang. Potensi peserta didik adalah kapasitas atau kemampuan dan karakteristik/sifat individu yang berhubungan dengan sumber daya manusia yang memiliki kemungkinan dikembangkan dan atau menunjang pengembangan potensi lain yang terdapat dalam diri peserta didik. Berbagai pengertian ini menegaskan bahwa setiap peserta didik memiliki kesanggupan, daya, dan mampu berkembang. Artinya, tidak boleh vonis kepada peserta didik tertentu bahwa ia tidak sanggup, berdaya, dan tidak mampu berkembang. 
Pada dasarnya setiap peserta didik mempunyai potensi, baik fisik, intelektual, kepribadian, minat, moral, maupun religi. Potensi fisik tidak hanya mengacu pada kondisi kesehatan fisik dan keberfungsian anggota tubuh tetapi juga berhubungan dengan proporsi pertumbuhan dan perkembangan fisik, perkembangan dan keterampilan psikomotorik. Potensi kepribadian mengacu pada kemampuan mengelola emosi, mengembangkan dan menjaga motivasi belajar, memimpin, beradaptasi, berinteraksi, berkomunikasi, responsibilitas, orientasi nilai, moral dan religi, sikap, dan kebiasaan. Sementara potensi intelektual sudah pasti berhubungan dengan kecerdasan yaitu prestasi akademik, kecerdasan umum, kemampuan khusus (bakat), dan kreativitas (Missa 2014).

\section{d. Indikator Siswa Memiliki Moralitas Keagamaan}

Moral adalah pengaturan perbuatan manusia sebagai manusia ditinjau dari segi baik-buruknya dipandang dari hubungannya dengan tujuan akhir hidup manusia berdasarkan hokum kodrat. Moral menuntut bukan hanya perbuatan lahiriah manusia, melainkan juga batin manusia. Manusia secara total sebagai pribadi, sebagai mahluk sosial, maupun sebagai mahluk beragama tunduk kepada moral.

Moral merupakan spesifikasi pendidikan nilai di sekolah yang mana diajarkan dalam pelajaran pendidikan agama islam (PAI). Dengan diberikannya pendidikan moral dilingkungan formal, maka siswa akan tahu informasi-informasi akan nilai-nilai yang baik yang dapat meningkatkan moral siswa. Untuk itu, siswa terlebih dahulu harus mampu membedakan mana yang baik dan buruk untuk diterapkan dalam pergaulan.

Adapun indikator siswa yang memiliki moralitas keagamaan, yaitu: a) Memiliki akhlak yang mulia dan kepribadian yang tinggi, b) Menjaga kebersihan, dari segi fisik maupun mental, c) Dapat memahami situasi, d) Memiliki sifat murah hati, saling memahami serta peka terhadap keperluan orang lain, e) Memiliki sikap tanggung jawab, f) Mempunyai sikap hormat menghormati (Kusuma 2013).

\section{Kontribusi Pesantren dalam Meningkatkan Moralitas Keagamaan}

\section{a. Pesantren dan Kesadaran Nilai Kemanusiaan}

Keberadaan pondok pesantren di era modern merupakan fenomena tersendiri dalam dunia pendidikan sehingga menimbulkan hipotesis bahwa cara yang ditempuh pondok pesantren dalam mempertahankan eksistensi layak untuk diteliti. Hal ini disebabkan pondok pesantren merupakan lembaga pendidikan 
yang muncul jauh sebelum Indonesia terbentuk dan hingga sampai saat ini keberadaannya layak untuk diperhitungkan di era moderen. Jika dilihat dari sudut pandang historis maka pondok pesantren adalah pewaris sah khazanah intelektual Indonesia terutama dalam khazanah keislaman.

Pada zama revolusi pesantren merupakan pusat gerilya dalam peperangan melawan belanda untuk merebut kemerdekaan. Banyak santri membentuk barisan hisbullah yang kemudian menjadi salah satu embrio bagi tentara nasional indoneisa. Ciri khas angkatan darat pada masa-masa awalnya menggambrkan adanya corak kepesantrenan, sebagaimana dikatakan oleh B.J. Boland (Mastuhu 1994).

Uraian diatas tersebut menggambarkan sebagaian bukti bahwa pesantren mampu mengembangan tantangan zamannya, sehingga bobot pesantren menjadi tinggi di mata bangsa, masyarakat, keluarga dan anak muda. Pada waktu itu pesantren merupakan tempat belajar yang sangat bergengsi, atau idola bagi generasi muda muslim.

Anak-anak keluarga muslim merasa rendah jika mereka tidak dapat memasuki dunia pesantren, dan keluarga mereka sangat bangga jika mereka dapat mengirimkan anaknya ke pesantren. Bertambah besar kiai, dan bertambah jauh pesantren yang di kunjungi, bertambah tinggi harga sosial seseorang dimata masyarakat (Mastuhu 1994).

Tetapi sejak sekitar dua dasawarsa terakhir ini mulai menurun harganya di mata bangsa, masyarakat, keluarga dan anak muda. Pesantren di anggap kurang mampu memenuhi aspirasi mereka dan tidak mampu memenuhi tantangan pembangunan (Mastuhu 1994). Secara kualitatif mereka meninggalkan pesantren secara kuantitatif mereka tetap belajar di pesantren. Sementara itu, masuk pesantren lebih murah dan mudah di bandingkan dengan masuk di sekolah umum, karena memang tidak ada syarat-syarat tertentu untuk masuk pesantren, berapa saja, kapan saja siswa dapat di terima. Namun hati masyarakat sbenarnya mendua, di satu segi mereka mengharapkan dan percaya pesantren dapat memberikan bekal moral agama bagi anak-anak mereka dalam mengarungi kehidupan modern, tetapi di segi lain mereka takut kalau pesantren tidak dapat membekali kemampuan kerja anak mereka dalam menghadapi masa depannya.

Meskipun pesantren telah terbukti memberikan kontribusi besar dalam mencerdaskan kehidupan bangsa, pondok pesantren tentunya juga masih memiliki beberapa kelemahan yang harus diperbaiki. Mensitir pernyataan Said Agil Siraj 
(2007), ada tiga hal yang belum dikuatkan dalam pesantren. Pertama, tamaddun yaitu memajukan pesantren. Banyak pesantren yang dikelola secara sederhana. Manajemen dan administrasinya masih bersifat kekeluargaan dan semuanya ditangani oleh kiainya. Dalam hal ini, pesantren perlu berbenah diri.

Kedua, tsaqafah, yaitu bagaimana memberikan pencerahan kepada umat Islam agar kreatif-produktif, dengan tidak melupakan orisinalitas ajaran Islam. Salah satu contoh para santri masih setia dengan tradisi kepesantrenannya. Tetapi, mereka jugaakrab dengan komputer dan berbagai ilmu pengetahuan serta sains modern lainnya. Ketiga, hadharah, yaitu membangun budaya. Dalam hal ini, bagaimana budaya kita dapat diwarnai oleh jiwa dan tradisi Islam. Di sini, pesantren diharapkan mampu mengembangkan dan mempengaruhi tradisi yang bersemangat Islam di tengah hembusan dan pengaruh dahsyat globalisasi yang berupaya menyeragamkan budaya melalui produk- produk teknologi.

\section{b. Kontribusi Positif Pesantren Bagi Masyarakat}

Pesantren menurut banyak kalangan memiliki kontribusi dalam pengembangan masyarakat. Hal ini mengingat bahwa nilai-nilai yang dikembangkan di lembaga pendidikan islam tersebut sarat dengan nilai persaudaraan dan prinsip-prinsip lain untuk penataan kehidupan bermasyarakat. Relasi antara pesantren dan masyarakat tidak heran berlangsung dalam suasana penuh kedekatan dan persaudaraan. Masyarakat di satu sisi menerima manfaat keberadaan pesantren dalam hal transmisi dan transfer ilmu pengetahuan keislaman (Oktavia et al. 2014), di sisi lain pesantren memiliki watak yang tak bisa di lepaskan dari pengembangan dan pemberdayaan masyarakat. Dengan lain ungkapan, kedekatan antara pesatren dan masyarakat yang terjalin dalam suasana mutualistik dalam melahirkan komposisi masyarakat yang berkapasitas dan santri-santri pesantren yang tidak saja intelek secara keilmuan, tetapi juga memiliki kearifan dan kebijakan dalam proses internalisasi keislaman di tengah kehidupan masyarakat.

Perkembangan masyarakat dewasa ini menghendaki adanya pembinaan anak didik yang dilaksanakan secara seimbang antara nilai dan sikap, pengetahuan, kecerdasan dan ketrampilan, kemampuan berkomunikasi dengan masyarakat secara luas, serta meningkatkan kesadaran terhadap alam lingkungannya. Asas pendidikan yang demikian itu diharapakan dapat merupakan upaya pembudayaan untuk mempersiapkan warga guna melakukan suatu pekerjaan yang menjadi mata pencahariannya dan berguna bagi masyarakatnya, 
serta mampu menyesuaikan diri secara konstruktif terhadap perubahanperubahan yang terjadi di lingkungan sekitarnya. Untuk memenuhi tuntutan pembinaan dan pengembangan masyarakat berusaha mengerahkan segala sumber dan kemungkinan yang ada agar pendidikan secara keseluruhan mampu mengatasi berbagai problem yang dihadapi masyarakat dan bangsa.

Kini masyarakat dan bangsa di hadapkan dengan berbagai masalah dan persoalan yang mendesak, masalah-masalah yang paling menonjol ialah tekanan masalah penduduk, krisis ekonomi, pengangguran, arus urbanisasi dan lainnya. Sementara krisis nilai, terancamnya kepribadian bangsa, dekadensi moral semakin sering terdengar.

Dalam upaya mengerahkan segala sumber yang ada dalam bidang pendidikan untuk memecahkan berbagai masalah tersebut, maka ekstensi pondok pesantren akan lebih disorot. Karena masyarakat dan Pemerintah mengharapkan pondok pesantren yang memiliki potensi yang besar dalam bidang pendidikan. Watak otentik pondok pesantren yang cenderung menolak pemusatan (sentralisasi), merdeka dan bahkan desentralisasi dan posisinya di tengah-tengah masyarakat, pondok pesantren sangat bisa diharapkan memainkan peranan pemberdayaan (enpowerment) dan transformasi masyarakat secara efekif, diantaranya adalah sebagai berikut:

\section{1) Peranan instrumental dan fasilitator}

Hadirnya pondok pesantren yang tidak hanya sebagai lembaga pendidikan dan keagamaan, namun juga sebagai lembaga pemberdayaan umat merupakan petunjuk yang amat berarti. Bahwa pondok pesantren menjadi sarana bagi pengembangan potensi dan pemberdayaan umat, seperti halnya dalam kependidikan atau dakwah islamiyah, sarana dalam pengembangan umat ini tentunya memerlukan sarana bagi pencapaian tujuan. Sehingga pondok pesantren yang mengembangkan hal-hal yang demikian berarti pondok pesantren tersebut telah berperan sebagai alat atau instrumen pengembangan potensi dan pemberdayaan umat. Beberapa peran pesantren ditengah masyarakat diantaranya:

\section{2) Peranan mobilisasi}

Pondok pesantren merupakan lembaga yang berperan dalam mobilisasi masyarakat dalam perkembangan mereka. Peranan seperti ini jarang dimiliki oleh lembaga atau perguruan lainnya, dikarenakan hal ini dibangun atas dasar kepercayaan masyarakat bahwa pondok pesantren adalah tempat yang tepat 
untuk menempa akhlak dan budi pekerti yang baik. Sehingga bagi masyarakat tertentu, terdapat kecenderungan yang memberikan kepercayaan pendidikan hanya kepada pondok pesantren.

\section{3) Peranan sumber daya manusia}

Dalam sistem pendidikan yang dikembangkan oleh pondok pesantren sebagai upaya mengoptimalkan potensi yang dimilikinya, pondok pesantren memberikan pelatihan khusus atau diberikan tugas magang di beberapa tempat yang sesuai dengan pengembangan yang akan dilakukan di pondok pesantren. Di sini peranan pondok sebagai fasilitator dan instrumental sangat dominan.

\section{4) Sebagai agent of development}

Pondok pesantren dilahirkan untuk memberikan respon terhadap situasi dan kondisi sosial suatu masyarakat yang tengah dihadapakan pada runtuhnya sendi-sendi moral, melalui transformasi nilai yang ditawarkan. Kehadirannya bisa disebut sebagai agen perubahan sosial (agent of social change), yang selalu melakukan pembebasan pada masyarakat dari segala keburukan moral, penindasan politik, kemiskinan ilmu pengetahuan, dan bahkan dari pemiskinan ekonomi.

\section{5) Sebagai center of excellence}

Institusi pondok pesantren berkembang sedemikian rupa akibat persentuhan-persentuhannya dengan kondisi dan situasi zaman yang selalu berubah. Sebagai upaya untuk menjawab tantangan zaman ini, pondok pesantren kemudian mengembangkan peranannya dari sekedar lembaga keagamaan dan pendidikan, menjadi lembaga pengembangan masyarakat (center of excellence).

\section{Terbentukanya Moralitas Keagamaan Santri Sebagai Salah satu Kontribusi Pondok Pesantren.}

Kiai Sahal Mahfud pernah menyinggung tentang apresiasi terhadap kedekatan jarak antara pesantren dan masyarakat ini :

Semakin dekat suatu pesantren dengan masyarakatnya semakin terbuka kemungkinan bagi pesantren untuk memahami segala problematikanya yang terjadi dalam masyarakat tersebut, hal mana memberinya wawasan yang cukup memadai untuk merumuskan langkah-langkah edial, yang tidak hanya benar menurut standart pesantren tetapi juga realistic 
menurut standart kehidupan sehari-hari masyarakat. Bersama dengan itu, semakin kuat pulalah legitimasi yang diberikan masyarakat

Dari ungkapan di atas dapat di katakana bahwa pesantren sebagai lembaga pendidikan islam tidak bisa di lepaskan dari perannya sebagai lembaga dakwah dalam pengertian luas,yakni melakuakan transformasi nilai nilai keislaman di tengah masyarakat.aspek amar makruf dan nahi mungkar sebagaimana direkomindasikan agama dalam hal ini dapat saja berlanagsung secara efektif, jika kedua pihak,antara pesantren dan masysrakat sekitar, berlangsung dalam susunan batin yang mendukung. Berbeda dengan suasana yang penuh resisten dalam kehadiran dan peranannyadi masyarakat,pesantren dapat saja di anggap memiliki kelemahan baik dalam keilmuan maupun strategi dalam bekerja samadengan masyarakat.untuk kasus seperti ini tentu membutuhkan pendifinisian ulang atas ajaran dan doktrin yang diajarkan di pesantren dan memonitoring serta mengevaluasi peran dakwah di tengah masyarakat.

\section{a. Indikator Pondok Pesantren Memiliki Kontribusi Dalam Membentuk Moralitas Keagamaan}

Pondok pesantren sebagai lembaga pendidikan telah ikut mengambil bagian dalam mencerdaskan rakyat, membina watak dan kepribadian bangsa. Terbukti puluhan juta penduduk telah mengalami proses pendidikan melalui sejumlah puluhan ribu pondok pesantren yang tersebar di seluruh Indonesia sejak jauh sebelum adanya sekolah-sekolah.

Dengan demikian pondok pesantren diharapkan mampu mencetak manusia muslim selaku kader-kader penyuluh atau pelopor pembangunan yang taqwa, cakap, berbudi luhur untuk bersama-sama bertanggung jawab atas pembangunan dan keselamatan bangsa serta mampu menempatkan dirinya dalam mata rantai keseluruhan sistem pendidikan nasional, baik pendidikan formal maupun non formal dalam rangka membangun manusia seutuhnya.

Pondok pesantren menurut banyak kalangan memiliki kontribusi dalam pengembangan masyarakat. Hal ini mengingat bahwa nilai-nilai yang dikembangkan di lembaga pendidikan islam tersebut sarat dengan nilai persaudaraan dan prinsip-prinsip lain untuk penataan kehidupan bermasyarakat (Oktavia et al. 2014).

Adapun kontribusi Pesantren dalam membentuk moralitas keagamaan diantaranya adalah: a) Melakukan komunikasi yang akarab antara santri dengan kyainya, b) Santri dididik untuk patuh kepada kyai nya, c) Santri dididik untuk 
hidup sederhana, d) Santri dididik untuk hidup mandiri, e) Santri dididik untuk saling tolong menolong dan memiliki rasa persaudaraan, f) Santri dididik untuk bersikap disiplin, g) Santri dididik untuk melakukan keprihatinan seperti Riyadhoh, h) Pemberian ijazah (Masyhud and Khusnurridlo 2013).

\section{b. Berbagai Alasan Pondok Pesantren Memiliki Kontribusi Dalam Membina Moralitas Keagamaan Dengan Sangat Baik}

\section{1) Sistem Pendidikan di Pesantren}

Dinamika sistem pendidikan di pesantren ialah gerak perjuangan pesantren di dalam memantapkan identitas dan kehadirannya di tengah tengah kehidupan bangsa yang sedang membangun ini, sebagai subsistem pendidikan nasional. Makin mantap dan kokoh kedudukannya serta semakin besar peran dan sumbanganya dalam memenuhi kebutuhan nasioanal melalui upaya pencapaian tujuan pendidikan nasional, akan semakin jelas identitasnya dan oleh karenanya akan semakin dinamis gerak perjuangannya. Hal sedemikin ini akan tercapai jika pesantren mampu mempertahankan identitasnya di satu pihak dan terbuka bagi kemajuan ilmu dan teknologi di pihak yang lain, dalam rangka mencapai cita cita nasioanal.

Sebagiman penjelasan mengenai sistem pendidikan di atas,sistem pendidikan di pesantren juga tediri atas unsur unsur dan nilai nilai yang merupakan satu kesatuan.kualitas dari dinamika suatu sistem di pesantren sangat tergantung pada kualitas para pengasuhnya dan bobot intraksi antara unsure unsurnya,terutama orientasi unsure unsure organiknya atau para pelakunya dalam menghadapi tantangan pembagunan nasioanal dan kemajuanilmu pengetahuan dan teknologi (Mastuhu 1994).

\section{2) Strategi Pembinaan Moraliatas Keagamaan di Pondok Pesantren Alhamdaniyah}

Potret pesantren dapat di lihat dari berbagai segi sestem pendidikan pesantren scera menyeluruh, yang meliputi materi pelajaran dan metode pengajaran, prinsip prinsip pendidikan, sarana dan tujuan pendidikan pesantren,kehidupan kiai dan santri serta hubungan keduanya,masing masing bisa diuraikan sebagai berikut.

Ada 6 metode yang diterapkan dalam membentuk perilaku santri, yakni: pertama, metode Keteladanan (Uswah Hasanah), kedua, latihan dan Pembiasaan, 
ketiga, mengambil Pelajaran (ibrah), keempat, nasehat (mauidzah), kelima, Kedisiplinan, keenam, pujian dan Hukuman (targhib wa tahzib)

Maka seperti itulah keadaan moralitas keagamaan siswa MTs Faqih Hasyim Siwalan Panji Buduran Sidoarjo yang memiliki moralitas rata- rata seperti kebanyakan siswa disekolahan lain, bedanya siswa Faqih Hasyim lebih terkontrol karna dalam satu ruang lingkup pondok pesantren, yaitu pesantren AlHamdaniyah.

Perspektif historis menempatkan pesantren pada posisi yang cukup istimewa dalam khazanah perkembangan social- budaya masyarakat Indonesia. Abdurrahman Wachid menempatkan pesantren sebagai subkultur tersendiri dalam masyarakat Indonesia. Menurutnya, lima ribu buah pondok pesantren yang tersebar di enam puluh delapan ribu desa merupakan bukti tersendiri untuk menyatakan sebagai sebuah subcultural (Masyhud and Khusnurridlo 2013).

Dalam konteks ini, praktek pembangunan social itu bukan saja menjadi milik dan tanggung jawab institusi pemerintahan, melainkan tanggungjawab bersama antara pemerintah dan masyarakat. Cuma, keberadaan pesantren tidak memiliki kewenangan langsung untuk merumuskan aturan sehingga perannya dapat dikategorikan ke dalam apa yang dikenal dengan partisipasi.

Membiasakan santri untuk melakukannya. Dalam pendidikan di pesantren metode ini biasanya akan diterapkan pada ibadah-ibadah amaliyah, seperti shalat berjamaah, kesopanan pada kiai dan ustadz. Pergaulan dengan sesama santri dan sejenisnya. Sedemikian, sehingga tidak asing di pesantren dijumpai, bagaimana santri sangat hormat pada ustadz dan kakak-kakak seniornya dan begitu santunnya pada adik-adik pada junior, mereka memang dilatih dan dibaisakan untuk bertindak demikian Latihan dan pembiasaan ini pada akhirnya akan menjadi akhlak yang terpatri dalam diri dan menjadi yang tidak terpisahkan.

\section{3) Mendidik melalui ibrah (mengambil pelajaran)}

Secara sederhana, ibrah berarti merenungkan dan memikirkan, dalam arti umum bisanya dimaknakan dengan mengambil pelajaran dari setiap peristiwa. Abd. Rahman al-Nahlawi[19], seorang tokoh pendidikan asal timur tengah, mendefisikan ibrah dengan suatu kondisi psikis yang manyampaikan manusia untuk mengetahui intisari suatu perkara yang disaksikan, diperhatikan, diinduksikan, ditimbang-timbang, diukur dan diputuskan secara nalar, sehingga 
kesimpulannya dapam mempengaruhi hati untuk tunduk kepadanya, lalu mendorongnya kepada perilaku yang sesuai.

Tujuan Paedagogis dari ibrah adalah mengantarkan manusia pada kepuasaan pikir tentang perkara agama yang bisa menggerakkan, mendidik atau menambah perasaan keagamaan. Adapun pengambilan ibrah bisa dilakukan melalui kisah-kisah teladan, fenomena alam atau peristiwa-peristiwa yang terjadi, baik di masa lalu maupun sekarang.

\section{4) Mendidik melalui mauidzah (nasehat)}

Mauidzah berarti nasehat Rasyid Ridla mengartikan mauidzah sebagai berikut: "Mauidzah adalah nasehat peringatan atas kebaikan dan kebenaran dengan jalan apa yang dapat menyentuh hanti dan membangkitkannya untuk mengamalkan". Metode mauidzah, harus mengandung tiga unsur, yakni : (a) Uraian tentang kebaikan dan kebenaran yang harus dilakukan oleh seseorang, dalam hal ini santi, misalnya tentang sopan santun, harus berjamaah maupun kerajinan dalam beramal; (b) Motivasi dalam melakukan kebaikan; (c) Peringatan tentang dosa atau bahaya yang bakal muncul dari adanya larangan bagi dirinya sendiri maupun orang lain.

\section{5) Mendidik melalui kedisiplinan}

Dalam ilmu pendidikan, kedisiplinan dikenal sebagai cara menjaga kelangsungan kegiatan pendidikan. Metode ini identik dengan pemberian hukuma atau sangsi. Tujuannya untuk menumbuhkan kesadaran siswa bahwa apa yang dilakukan tersebut tidak benar, sehingga ia tidak mengulanginya lagi.

Pembentukan lewat kedisiplinan ini memerlukan ketegasan dan kebijaksanaan. Ketegasan mengharuskan seorang pendidik memberikan sangsi bagi pelanggar, sementara kebijaksanaan mengharuskan sang pendidik sang pendidik berbuat adil dan arif dalam memberikan sangsi, tidak terbawa emosi atau dorongan lain. Dengan demikian sebelum menjatuhkan sangsi, seorang pendidik harus memperhatikan beberapa hal berikut: (a) perlu adanya bukti yang kuat tentang adanya tindak pelanggaran; (b) hukuman harus bersifat mendidik, bukan sekedar memberi kepuasan atau balas dendam dari si pendidik; (c) harus mempertimbangkan latar belakang dan kondisi siswa yang melanggar, misalnya frekuensinya pelanggaran, perbedaan jenis kelamin atau jenis pelanggaran disengaja atau tidak. 
Di pesantren, hukuman ini dikenal dengan istilah takzir. Takzir adalah hukuman yang dijatuhkan pada santri yang melanggar. Hukuman yang terberat adalah dikeluarkan dari pesantren. Hukuman ini diberikan kepada santri yang telah berulang kali melakukan pelanggaran, seolah tidak bisa diperbaiki. Juga diberikan kepada santri yang melanggar dengan pelanggaran berat yang mencoreng nama baik pesantren.

\section{6) Mendidik melalui targhib wa tahzib}

Metode ini terdiri atas dua metode sekaligus yang berkaitan satu samalain; targhib dan tahzib. Targhib adalah janji disertai dengan bujukan agar seseorang senang melakukan kebajikan dan menjauhi kejahatan. Tahzib adalah ancaman untuk menimbulkan rasa takut berbuat tidak benar. Tekanan metode targhib terletak pada harapan untuk melakukan kebajikan, sementara tekanan metode tahzib terletak pada upaya menjauhi kejahatan atau dosa.

Meski demikian metode ini tidak sama pada metode hadiah dan hukuman. Perbedaan terletak pada akar pengambilan materi dan tujuan yang hendak dicapai. Targhib dan tahzib berakar pada Tuhan (ajaran agama) yang tujuannya memantapkan rasa keagamaan dan membangkitkan sifat rabbaniyah, tanpa terikat waktu dan tempat. Adapun metode hadiah dan hukuman berpijak pada hukum rasio (hukum akal) yang sempit (duniawi) yang tujuannya masih terikat ruang dan waktu. Di pesantren, metode ini biasanya diterapkan dalam pengajian-pengajian, baik sorogan maupun bandongan.

\section{7) Mendidik melalui kemandirian}

Kemandirian tingkah-laku adalah kemampuan santri untuk mengambil dan melaksanakan keputusan secara bebas. Proses pengambilan dan pelaksanaan keputusan santri yang biasa berlangsung di pesantren dapat dikategorikan menjadi dua, yaitu keputusan yang bersifat penting-monumental dan keputusan yang bersifat harian. Pada tulisan ini, keputusan yang dimaksud adalah keputusan yang bersifat rutinitas harian.

Terkait dengan kebiasan santri yang bersifat rutinitas menunjukkan kecenderungan santri lebih mampu dan berani dalam mengambil dan melaksanakan keputusan secara mandiri, misalnya pengelolaan keuangan, perencanaan belanja, perencanaan aktivitas rutin, dan sebagainya. Hal ini tidak lepas dari kehidupan mereka yang tidak tinggal bersama orangtua mereka dan tuntutan pesantren yang menginginkan santri-santri dapat hidup dengan 
berdikari. Santri dapat melakukan sharing kehidupan dengan teman-teman santri lainnya yang mayoritas seusia (sebaya) yang pada dasarnya memiliki kecenderungan yang sama. Apabila kemandirian tingkah-laku dikaitkan dengan rutinitas santri, maka kemungkinan santri memiliki tingkat kemandirian yang tinggi.

\section{Simpulan}

Beberapa argumentasi yang telah dibangun dalam artikel ini menunjukkan dua hal sebagai simpulan akhir. Pertama, Kontribusi pondok pesantren Alhamdaniyah pada MTs Faqih Hasyim antara lain melaksanakan Istighosah dan Tahlilan setiap hari jum'at pagi yang di pimpin langsung oleh kepala Sekolah MA Faqih Hasyim yang termasuk keluarga pesantren Alhamdaniyah. Dan diikuti oleh siswa MTs dan MA Faqih Hasyim Siwalanpanji. ada juga pelajaran ta'limul muta'alim bagi siswa kelas VII, VIII, dan IX. Kedua, pondok pesantren Alhamdaniyah memiliki kontribusi yang sangat kuat untuk membina moralitas keagamaan siswa Faqih Hasyim yang dapat digambarkan, seperti siswa memiliki jiwa agamis yang nantinya bisa menjadikan moral siswa lebih baik, siswa tidak melupakan nilai-nilai keagamaan yang sudah dilakukan oleh para ulama'-ulama' salaf, siswa memiliki ikatan yang erat dengan penciptanya dan terjalin hubungan yang baik antara pondok pesantren dengan sekolah.

\section{Daftar Pustaka}

Bertens, K. 2013. Etika. Yogyakarta: Kanisius.

Dhurkheim, Emile. 2013. Pendidikan Moral. Jakarta: Erlangga.

Kafrawi. 1978. Pembaruan Sistem Pendidikan Pesantren. Jakarta: Cemara Indah.

Kemenag RI. 2009. Al-Qur'an Dan Terjemah. Jakarta: Kementerian Agama RI.

Kusuma, Dharma. 2013. Pendidikan Karakter. Bandung: Remaja Rosdakarya.

Mastuhu. 1994. Dinamika Sistem Pendidikan Pesantren. Jakarta: INIS.

Masyhud, MS, and M Khusnurridlo. 2013. Manajemen Pondok. Jakarta: Diva Pustaka.

Missa, Daniel Yonathan Missa. 2014. Potensi-Peserta Didik. Kompasiana.Com. https://www.kompasiana.com/potensi-peserta-didik.

Nata, Abuddin. 2013. Akhlak Tasawwuf Dan Karakter Mulia. Jakarta: Raja Grafindo Persada. 
Nugroho, Puspo. 2017. Internalisasi Nilai-Nilai Karakter Dan Kepribadian Mahasiswa Pendidikan Agama Islam Melalui Pendekatan Humanis-Religius. Edukasia: Jurnal Penelitian Pendidikan Islam 12(2): 355-382.

Nugroho, Puspo. 2018. Tripusat Pendidikan Sebagai Basis Sosialisasi dan Pembentukan Karakter Siswa. Ijtimaiya: Journal of Science Teaching 2(1).

Oktavia, Lanny, Ibi Syatibi, Mukti Ali, Roland Gunawan, and Ahmad Hilmi. 2014. Pendidikan Karakter Berbasis Tradisi Pesantren. Jakarta: Rumah Kitab.

Subandi. 2009. Psikologi Dzikir. Yogyakarta: Pustaka Pelajar. 